JBAT 8(1) (2019) 28-33
Jurnal Bahan Alam Terbarukan
$\begin{gathered}\text { Terakreditasi: SK No.: 36b/E/KPT/2016 } \\ \text { http://journal .unnes.ac.id/nju/index.php/jbat }\end{gathered}$

\title{
Synthesis of Phosphorylated Sugar Palm (Aren) Starch Using Low Level Sodium Tripolyphosphate (STPP)
}

\section{Asaf Kleopas Sugih ${ }^{\bowtie}$, Jordi Loanda, Susiana Prasetyo}

DOI 10.15294/jbat.v8i1.17685

Chemical Engineering Department, Parahyangan Catholic University, J1. Ciumbuleuit 94, Bandung, Indonesia

\begin{tabular}{|c|c|}
\hline Article Info & Abstract \\
\hline $\begin{array}{l}\text { Article history: } \\
\text { Received } \\
\quad \text { December } 2018 \\
\text { Accepted } \\
\quad \text { January } 2018 \\
\text { Published } \\
\quad \text { June } 2018 \\
\text { Keywords : } \\
\text { Aren; } \\
\text { Arenga pinnata; } \\
\text { Phosphorylation; } \\
\text { Starch; } \\
\text { Sugar palm }\end{array}$ & $\begin{array}{l}\text { Sugar palm or aren (Arenga pinnata) is a traditional source of starch widely cultivated } \\
\text { throughout Indonesia. Despite its potentiality to be used as feedstock for food industries, } \\
\text { there has been very little research reported on sugar palm starch characterization and } \\
\text { modification. This paper describes a preliminary experimental study on the chemical } \\
\text { modification, i.e. phosphorylation of sago palm starch using low level of Sodium } \\
\text { tripolyphosphate (STPP), and characterization of some important physicochemical and } \\
\text { functional properties of the modified products. Starch phosphate synthesis was conducted at } \\
\text { an initial pH of } 9 \text {, reaction temperatures of } 120-140{ }^{\circ} \mathrm{C} \text {, and STPP intakes of } 0.5-1.5 \% \text {-weight } \\
\text { based on dry starch. The experimental result shows that Degree of Substitution (DS) of the } \\
\text { obtained products is accessible in the range of } 0.0013-0.0068 \text {. An increase in reaction } \\
\text { temperature as well as STPP intake leads to products with higher DS values. The modified } \\
\text { starch products exhibit higher swelling power ( } 16.57-24.81 \text { g/g) and solubility }(9.12-22.79 \% \text { - } \\
\text { w/w) compared to native sugar palm starch (swelling power and solubility of } 14.50 \text { g/g and } \\
7.91 \% \text {-w/w, respectively). Phosphorylated starch products also have significantly improved } \\
\text { paste clarity clarity and water/ oil absorption capacity compared to native sugar palm starch. } \\
\text { The result suggests that phosphorylation is a promising method to enhance the properties of } \\
\text { sugar palm starch. }\end{array}$ \\
\hline
\end{tabular}

\section{INTRODUCTION}

Aren/ enau, also known as sugar palm or dryland sago (Arenga pinnata) (Wina et al., 1986) is a natural forest species of humid tropical regions of Asia. Compared to other multiple purpose trees (MPTs) of palm family, aren has the widest range of use, involving virtually all parts of the plant (root, stem, fibers, leaves, sap, and fruit) (Mogea et al., 1991). Sugar palm starch is an important product of aren collected from the pith of trees that are no longer productive in terms of sugar and fruit production (Adawiyah et al., 2013). Sugar palm starch commands a premium over swamp sago (Metroxylon sago) flour (Wina et al., 1986), and is used in the preparation of various traditional food products such as wet noodle, soun, cendol, dodol, and kerupuk opak (Mogea et al., 1991). Despite its potentiality to be used as a feedstock for industrial applications, there has been very little research reported on sugar palm starch characterization (Wina et al., 1986; Adawiyah et al., 2013) or modification.

Starch has extensive potential uses in food as well as non-food industries. Native starch, however, has inferior properties that limit its applications. Hence, in most cases, the physicochemical and functional characteristics of starch must be upgraded through physical or chemical modification (Chiu \& Solarek, 2009). Phosphorylation is a potential chemical modification technique commonly applied to increase the hydrophilicity of starch, resulting in products suitable for food, paper, adhesive, textile,

\footnotetext{
$\triangle$ Corresponding author:

Chemical Engineering Department, Parahyangan Catholic University,

J1. Ciumbuleuit 94, Bandung, Indonesia

E-mail: asaf.k.sugih@unpar.ac.id
} 
as well as pharmaceutical industries (Solarek, 1986). Results from previous researches showed that phosphorylation technique has been successfully applied to improve the properties of rice, corn, wheat, sago, and mung bean starch (Lin et al., 2009; Lim \& Seib, 1993; Muhammad et al., 2000; Nathania et al., 2017). Nevertheless, to the best of our knowledge, no study has been reported on the phosphorylation of sago palm starch.

The aim of this research is to explore the potentiality of using low level sodium tripolyphosphate (STPP) as a reagent for sugar palm starch phosphorylation. In particular, the effect of STPP intake and reaction temperature on P-content and Degree of Substitution (DS) of the products was investigated. Several functional properties of the phosphorylated products (swelling power, solubility, water/ oil absorption capacity, and paste clarity) were characterized and compared to native sago palm starch.

\section{RESEARCH METHODOLOGY}

\section{Materials}

Sugar palm starch was obtained from local market in Bogor, West Java, and used without further purification. Proximate analysis revealed that this starch contains $0.20 \%-\mathrm{w} / \mathrm{w}$ ash, $0.24 \%$ $\mathrm{w} / \mathrm{w}$ lipid, $0.26 \%-\mathrm{w} / \mathrm{w}$ protein, and $99.30 \%$ carbohydrate (dry basis). Phosphorylation reaction was conducted using Sodium tripolyphosphate (STPP) reagent (technical grade) obtained from Sigma Aldrich, Singapore and sodium sulfate (analytical grade, Merck, Jakarta). The $\mathrm{pH}$ of the suspensions was adjusted using hydrochloric acid and sodium hydroxide (analytical grade, Merck, Jakarta). Reagents used for phosphate content determination (Vanadate Molybdate, potassium hydrogenphosphate, and sodium carbonate) were all of analytical grade and obtained from Merck, Jakarta. All chemicals were used without further purification.

\section{Methods}

\section{Preparation of Phosphorylated Starch Products}

Phosphorylated sugar palm starch products were prepared according to a previously reported method for wheat and corn starch phosphorylation (Lim \& Seib, 1993) with slight modification. A solution containing 0.5-1.5\%-w STPP/ w of starch (dry weight basis), $12 \mathrm{ml}$ of water, and 1 gram of sodium sulfate was prepared, and $\mathrm{pH}$ of the solution is adjusted to 9 using $\mathrm{HCl}$ or $\mathrm{NaOH}$ solution (10\%-mol/ mol). Sugar palm starch (10 gram, dry weight basis) was added into the solution, and $\mathrm{pH}$ was adjusted back to 9. The resulting starch suspension was stirred for one hour at room temperature, before subsequently dried in a tray dryer at $45{ }^{\circ} \mathrm{C}$. When water content of the starch mixture reached 10-15 \%-w/ w, the temperature of the drier was increased to $120-140$ ${ }^{\circ} \mathrm{C}$, and reaction was carried out for two more hours. The resulted phosphorylated starch products were cooled to room temperature and washed for three times (using $25 \mathrm{ml}$ of $\mathrm{RO}$ water, $\mathrm{pH}$ of the suspension was adjusted at $\mathrm{pH} 9$ ). Each time, the solid product was separated from the washing solution by centrifuging the mixture at $1500 \mathrm{~g}$ for 10 minutes. Phosphorylated starch products were finally dried in a tray dryer at $45{ }^{\circ} \mathrm{C}$ until constant weight. Each experiment was performed in duplicate.

\section{Product Characterization: Determination of DS and P-content}

Phosphorus content and Degree of Substitution (DS) of the phosphorylated starch products were determined spectrophotometrically at $\lambda=385 \mathrm{~nm}$ according to a previously reported procedure (Passauer et al., 2010). DS is calculated as $\mathrm{mol} \mathrm{P/} \mathrm{mol} \mathrm{of} \mathrm{anhydroglucose} \mathrm{(AHG)} \mathrm{units} \mathrm{of}$ sugar palm starch molecules.

\section{Product Characterization: Swelling Power and Solubility}

Swelling power and solubility of native and phosphorylated sugar palm starch products were determined according to a published method (Li \& Corke, 1999). Starch sample was mixed with RO water $\left(3.33 \%\right.$-w/ v) at $85^{\circ} \mathrm{C}$ for 30 minutes. The mixture was subsequently centrifuged $(3000 \mathrm{rpm}$, 15 minutes) to separate starch paste from supernatant containing soluble starch. Collected supernatant was dried at $100{ }^{\circ} \mathrm{C}$ until constant weight. Swelling Power (g/g) and Solubility (\%-w/ w) of the samples were calculated by using Eq. (1).

$$
\begin{aligned}
& \text { Swelling Power }= \\
& \frac{\text { weight of sediment paste }(g)}{\text { weight of initial sample }(g) \times\left(1-\frac{\text { Solubility }}{100}\right)} \\
& \text { Solubility }=\frac{\text { weight of soluble starch }(g)}{\text { weight of initial sample }(g)} \times 100 \%
\end{aligned}
$$


Table 1. Phosphorus Content and Degree of Substitution of Phosphorylated Starch Products

\begin{tabular}{ccccccc}
\hline \multirow{2}{*}{$\begin{array}{c}\text { Reaction } \\
\text { Temperature }\end{array}$} & \multicolumn{3}{c}{ P-Content (\%-w/ w) } & \multicolumn{3}{c}{ Degree of Substitution } \\
\cline { 2 - 7 }$\left({ }^{\mathbf{O}} \mathbf{C}\right)$ & \multicolumn{3}{c}{$\begin{array}{c}\text { STPP Intake } \\
\text { (\%-w/ w of Dry Starch) }\end{array}$} & \multicolumn{3}{c}{$\begin{array}{c}\text { STPP Intake } \\
\text { (\%-w/ w of Dry Starch) }\end{array}$} \\
\cline { 2 - 7 } & $\mathbf{0 . 5}$ & $\mathbf{1}$ & $\mathbf{1 . 5}$ & $\mathbf{0 . 5}$ & $\mathbf{1}$ & $\mathbf{1 . 5}$ \\
\hline 120 & 0.025 & 0.061 & 0.091 & 0.0013 & 0.0032 & 0.0049 \\
130 & 0.043 & 0.078 & 0.097 & 0.0023 & 0.0041 & 0.0051 \\
140 & 0.055 & 0.089 & 0.129 & 0.0029 & 0.0046 & 0.0068 \\
\hline
\end{tabular}

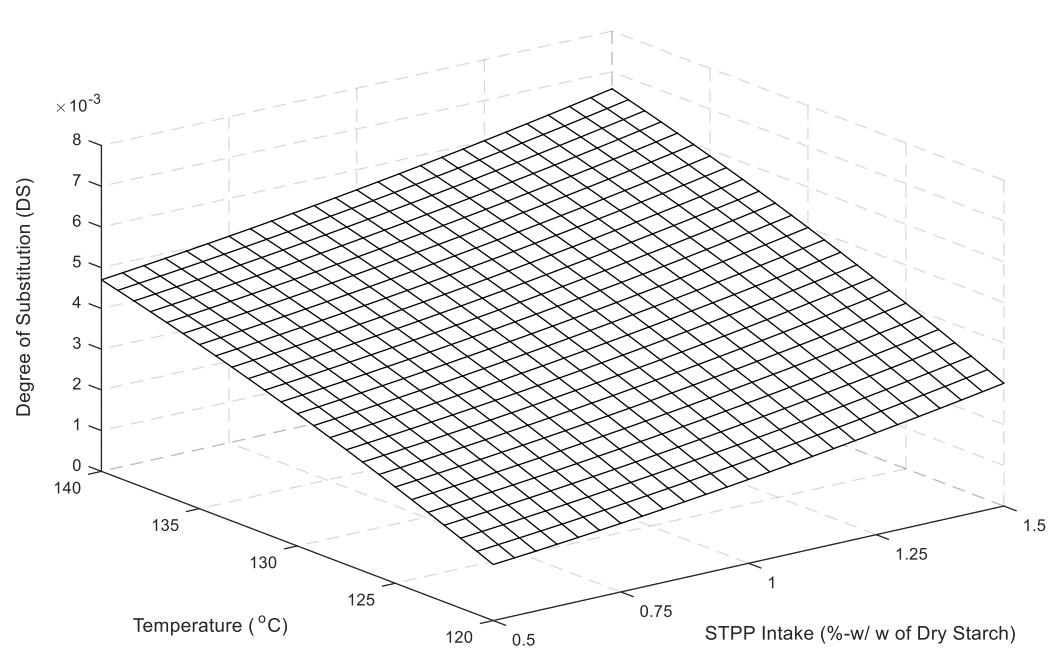

Figure 1. Degree of Substitution (DS) of Phosphorylated Starch Products (Based on Multivariable Regression Model).

\section{Product Characterization: Water and Oil Absorption Capacity}

Water and oil absorption capacity were determined based on a reported procedure (Mishra \& Rai, 2006) with a slight modification. Starch sample was mixed in $\mathrm{RO}$ water or palm cooking oil $(10 \%-\mathrm{w} / \mathrm{v})$ in a centrifuge tube and kept at room temperature ( 1 hour). The suspension was subsequently centrifuged (3000 rpm, $30 \mathrm{~min}$ ), and the separated sediment paste was collected and weighed. The absorption capacity was calculated as mass of water or oil (in g) absorbed per $g$ of the initial starch sample.

\section{Product Characterization: Paste Clarity}

Paste clarity of gelatinized starch suspensions was measured spectrophotometrically based on the procedure suggested by Stahl et al. (2007) with a slight modification. Paste clarity is defined as the percentage of transmittance (at $\lambda=$ $650 \mathrm{~nm})$ of starch suspensions in RO water ( $1 \%$-w/ $\mathrm{v}, \mathrm{pH}=7)$, heated at $85{ }^{\circ} \mathrm{C}$ for 30 mins and subsequently cooled to $25^{\circ} \mathrm{C}$ for 60 minutes before the measurement.

\section{RESULT AND DISCUSSION}

Phosphorylation of sugar palm starch was conducted at temperatures of 120,130 , and $140{ }^{\circ} \mathrm{C}$, with an intake of $0.5-1.5 \%-\mathrm{w}$ STPP/ w of dry starch. During the reaction, hydroxyl groups available at anhydroglucose (AHG) units of starch molecules attacked phosphate groups from STPP, and became substituted with mono- or diphosphates (Lim \& Seib, 1993). After isolation and drying steps, the phosphorylated starch product was obtained as white powder.

\section{P-Content and Degree of Substitution of Phosphorylated Starch Products}

Phosphorus content and DS of the phosphorylated sugar palm starch was determined spectrophotometrically, and the result is given in Table 1 . The P-content of the products ranges from $0.025-0.129 \%$, while the DS values are accessible in the range of 0.0013-0.0068. Apart from the slightly lower P-content values obtained for products synthesized at lowest STPP intake $(0.5 \%$-w/ w of dry starch), most of the P-content values are still comparable with the results reported previously for 
Table 2. Swelling Power and Solubility of Native and Phosphorylated Sugar Palm Starch Products

\begin{tabular}{ccccccc}
\hline \multirow{2}{*}{$\begin{array}{c}\text { Temperature } \\
\left({ }^{\mathbf{0}} \mathbf{C}\right)\end{array}$} & \multicolumn{3}{c}{ Swelling Power (g/ g) } & \multicolumn{3}{c}{ Solubility (\%-w/ w) } \\
\cline { 2 - 7 } & \multicolumn{2}{c}{$\begin{array}{c}\text { STPP Intake } \\
\text { (\%-w/ w of Dry Starch) }\end{array}$} & \multicolumn{3}{c}{$\begin{array}{c}\text { STPP Intake } \\
\text { (\%-w/ w of Dry Starch) }\end{array}$} \\
\cline { 2 - 7 } & $\mathbf{0 . 5}$ & $\mathbf{1}$ & $\mathbf{1 . 5}$ & $\mathbf{0 . 5}$ & $\mathbf{1}$ & $\mathbf{1 . 5}$ \\
\hline Native & & 14.50 & & & 7.91 & \\
120 & 16.57 & 18.82 & 21.49 & 9.12 & 13.70 & 17.38 \\
130 & 17.53 & 19.62 & 23.45 & 11.87 & 15.62 & 19.24 \\
140 & 18.75 & 22.03 & 24.81 & 13.66 & 18.25 & 22.79 \\
\hline
\end{tabular}

Table 3. Water Absorption Capacity (WAC) and Oil Absorption Capacity (OAC) of Native and Phosphorylated Sugar Palm Starch Products

\begin{tabular}{ccccccc}
\hline \multirow{2}{*}{$\begin{array}{c}\text { Temperature } \\
\left({ }^{\circ} \mathbf{C}\right)\end{array}$} & \multicolumn{3}{c}{$\begin{array}{c}\text { Water Absorption Capacity (g/ g) } \\
\text { STPP Intake }\end{array}$} & \multicolumn{3}{c}{ Oil Absorption Capacity (g /g) } \\
\cline { 2 - 7 } & $\mathbf{0}$ \%-w/ w of Dry Starch) & \multicolumn{3}{c}{$\begin{array}{c}\text { STPP Intake } \\
\text { (\%-w/ w of Dry Starch) }\end{array}$} \\
\cline { 2 - 7 } & $\mathbf{0 . 5}$ & $\mathbf{1}$ & $\mathbf{1 . 5}$ & $\mathbf{0 . 5}$ & $\mathbf{1}$ & $\mathbf{1 . 5}$ \\
\hline Native & & 0.73 & & & 0.55 & \\
120 & 0.86 & 0.90 & 0.96 & 0.62 & 0.64 & 0.67 \\
130 & 0.89 & 0.94 & 1.00 & 0.63 & 0.66 & 0.69 \\
140 & 0.92 & 0.98 & 1.25 & 0.65 & 0.68 & 0.72 \\
\hline
\end{tabular}

Table 4. Paste Clarity of Native and Phosphorylated Sugar Palm Starch Products

\begin{tabular}{cccc}
\hline & \multicolumn{3}{c}{ Paste Clarity (\%-T) } \\
\cline { 2 - 4 } Temperature $\left({ }^{\circ} \mathbf{C}\right)$ & \multicolumn{3}{c}{ STPP Intake } \\
& \multicolumn{2}{c}{ (\%-w/ w of Dry Starch) } \\
\cline { 2 - 4 } & $\mathbf{0 . 5}$ & $\mathbf{1}$ & $\mathbf{1 . 5}$ \\
\hline Native & & 37.65 & \\
120 & 58.60 & 62.15 & 65.65 \\
130 & 60.80 & 63.95 & 67.95 \\
140 & 62.00 & 65.40 & 70.25 \\
\hline
\end{tabular}

phosphorylated sago starch $(\mathrm{P}$ content $=0.05$ $0.32 \%$ ) (Muhammad et al., 2000), corn/ wheat starch (P content $=0.06-0.29 \%)($ Lim \& Seib, 1993), and our previous results on mung bean and arrowroot starch (P content $=0.045-0.250 \%)$ (Nathania et al., 2017; Sugih, et al., 2015). The Pcontent of phosphorylated sugar palm starch products are still far below Food Chemical Codex (FCC) permitted level for food purposes $(0.4 \%)$ (Committee on Food Chemical Codex, 2003), suggesting that the products are safe for human consumption.

In order to observe the dependence of the DS values on the experimental variables (reaction temperature and STPP intake), a simple non-linear multivariable regression model $\left(\mathrm{R}^{2}=0.9996\right)$ has been developed and the result is shown graphically in Figure 1. The use of higher STPP intakes provides starch with more available phosphate groups during the reaction, causing more replacement of starch hydroxyl groups (higher DS). This result shares a similar trend with our previous result on the phosphorylation of arrowroot starch (Sugih et al., 2015). Phosphorylation reaction rate will also be faster at higher temperature, resulting in products with increased DS values. This temperature effect is in agreement with previous observations on the phosphorylation of rice, sago, and arrowroot starch (Lin et al., 2009; Sugih et al., 2015; Sugih et al., 2013).

\section{Characterization of Phosphorylated Sugar Palm Starch Products}

Several functional properties of native and phosphorylated sugar palm starch (i.e. swelling power and solubility, water and oil absorption capacity, and paste clarity) were determined, and the results are shown in Tables 2-4. Swelling power and solubility of starch products were determined by mixing and heating starch/water suspension. 
Starch paste was subsequently isolated from the suspension after centrifugation. Swelling power of native sugar palm starch $(14.50 \mathrm{~g} / \mathrm{g})$ is higher compared to reported values for arrowroot, mung bean, sweet potato, and corn starch $(4.87-11.42 \mathrm{~g} / \mathrm{g})$ (Nathania et al., 2017; Stahl et al., 2007; Sugih et al., 2015; Sugih et al., 2016), but lower than swelling power of pinhao starch $(26.02 \mathrm{~g} / \mathrm{g}$ ) (Stahl et al., 2007). Its solubility $(7.91 \%-\mathrm{w} / \mathrm{w})$ is again relatively high compared to arrowroot, mung bean, sweet potato, and corn starch (1.669-7.26 \%-w/ w) but rather low compared to pinhao starch (22.07\%w/ w) (Nathania et al., 2017; Stahl et al., 2007; Sugih et al., 2015; Sugih et al., 2016). Substitution of starch hydroxyl groups with phosphate significantly improves the swelling power and solubility of sugar palm starch. Sitohy et al. (2000) hypothesized that introduction of phosphate groups reduces strong hydrogen bonds present in starch granules. As the result, water is allowed to penetrate into starch structure more easily, and swelling power and solubility of the products increases. Phosphorylated product with highest DS (0.0068) also has the highest swelling power $(24.81 \mathrm{~g} / \mathrm{g})$ and solubility $(22.79 \%$-w/ w), or about $170 \%$ and $290 \%$ of native sugar palm starch, respectively. These achieved values are much higher compared to reported swelling power and solubility values for other phosphorylated starches (the maximum values are $12.82 \mathrm{~g} / \mathrm{g}$ and $14.10 \%-\mathrm{w} / \mathrm{w}$, respectively) (Nathania et al., 2017; Sugih et al., 2015; Sugih et al., 2016), and only slightly lower compared to phosphorylated corn and pinhao starch with significantly higher DS of 0.15 (25.16$25.45 \mathrm{~g} / \mathrm{g}$ and $24.21-27.20 \%-\mathrm{w} / \mathrm{w}$, respectively) (Stahl et al., 2007).

Water and oil absorption capacity (WAC and $\mathrm{OAC}$ ) of native and phosphorylated starch products were measured by weighing starch pastes collected after centrifugation of starch/ water or starch/ oil mixtures prepared at room temperature. Native sugar palm starch has the lowest WAC $(0.73$ $\mathrm{g} / \mathrm{g})$ and OAC $(0.55 \mathrm{~g} / \mathrm{g})$ compared to reported values of other types of starch $(0.847-10.4 \mathrm{~g} / \mathrm{g}$ and $0.572-1.40 \mathrm{~g} / \mathrm{g}$, respectively) (Nathania et al., 2017; Mishra \& Rai, 2006; Sugih et al., 2015; Sugih et al., 2016). The presence of phosphate groups significantly increases WAC as well as OAC of sugar palm starch. Similar trend is also observed when phosphorylation was performed on other types of starch (Lim \& Seib, 1993; Nathania et al., 2017; Sugih et al., 2015; Sugih et al., 2016). The substitution of hydroxyl groups of starch with more polar phosphate groups resulted in attraction of more water molecules, resulting in higher WAC of the products. It is also hypothesized that at the same time, the presence of negatively charged phosphate reduces the strength of hydrogen bonds between anhydroglucose units of starch (Sitohy et al., 2000), providing more spaces inside the molecules that can be filled with more water or oil. Paste clarity was determined spectrophotometrically after heating and subsequently cooling starch pastes. Native sugar palm starch has rather high paste clarity $(37.65 \%)$ compared to corn, wheat, sweet potato, or mung bean starch (15.30-34\%) (Lim \& Seib, 1993; Nathania et al., 2017; Sugih et al., 2016). Phosphorylation significantly improves sugar palm starch paste clarity to $58.60-70.25 \%$. Similar results were observed for other types of starch (Lim \& Seib, 1993; Nathania et al., 2017; Li \& Corke, 1999; Stahl et al., 2007; Sitohy et al., 2000). It is suggested that negatively charged phosphate groups induces repulsion between neighboring starch molecules. As the result, starch hydration level increases and highly swollen particles with high light transmittance is formed (Lim \& Seib, 1993).

\section{CONCLUSION}

A preliminary study on the synthesis of phosphorylated sugar palm starch has been reported. Phosphorylation is successfully performed using STPP reagent (with intakes of 0.5 $-1.5 \% \mathrm{w} / \mathrm{w}$ of dry starch) at $110-130^{\circ} \mathrm{C}$. Modified products with DS $=0.0013-0.0068$ (corresponding to $\mathrm{P}$ content of $0.025-0.129 \%$, far below the permitted safe level for food application) have been obtained. Phosphorylation significantly improves swelling power and solubility, water/ oil absorption capacity, and paste clarity of sugar palm starch. In particular, sugar palm starch phosphate products exhibit very high swelling power and solubility compared to phosphorylated products from other types of starch. The obtained result suggests that phosphorylation is a potential method to improve functional properties of sugar palm starch. Further research is currently carried out to examine physicochemical and functional properties of phosphorylated sugar palm starch synthesized using different STPP and STMP intake ranges, and the result will be reported in forthcoming papers. 


\section{REFERENCES}

Adawiyah, D. R., Sasaki, T., Kohyama, K. 2013. Characterization of arenga starch in comparison with sago starch. Carbohydrate Polymers. 92: 2306- 2313.

Chiu, C. W., Solarek, D. 2009. Modification of Starches, in J. Bemiller and R. Whistler (Ed.). Starch: Chemistry and Technology, 3rd Ed. Academic Press. Burlington. 629.

Committee on Food Chemical Codex, Food and Nutrition Board, Institute of Medicine. 2003. Food Chemicals Codex. 5th Ed. The National Academies Press, Washington DC.

Li, J., Corke, H. 1999. Physicochemical Properties of Normal and Waxy Job's Tears (Coix lachryma-jobi L.) Starch. Cereal Chemistry. 76: 413-416.

Lim., S., Seib, P. A. 1993. Preparation and Pasting Properties of Wheat and Corn Starch Phosphates. Cereal Chemistry. 70: 137144.

Lin, Q., Xiao, H., Zhao, J., Li, L., Yu, F. 2009. Characterization of the Pasting, Flow and Rheological Properties of Native and Phosphorylated Rice Starches. Starch/ Starke. 61: 709-715.

Mishra, S., Rai, T. 2006. Morphology and functional properties of corn, potato and tapioca starches. Food Hydrocolloids. 20: 557-566.

Mogea, J., Seibert, B., Smits, W. 1991. Multipurpose palms: the sugar palm (Arenga pinnata (Wurmb) Merr.). Agroforestry Systems. 13: 111-129.

Muhammad, K., Hussin, F, Man, Y. C., Ghazali, H. M., Kennedy, J.F. 2000. Effect of $\mathrm{pH}$ on phosphorylation of sago starch. Carbohydrate Polymers. 42: 85-90.

Nathania, I., Sugih, A. K., Muljana, H. 2017. Preliminary Study on the Synthesis of Phosphorylated Mung Bean Starch: The Effect of $\mathrm{pH}$ on the Physicochemical and Functional Properties. Indonesian Journal of Chemistry. 17: 401-406.

Passauer, L., Bender, H., Fischer, S. 2010. Synthesis and characterisation of starch phosphates. Carbohydrate Polymers. 82: 809-814.
Sitohy, M. Z., El-Saadany, S. S., Labib, S. M., Ramadan, M. F. 2000. Physicochemical Properties of Different Types of Starch Phosphate Monoesters. Starch/Starke. 52: 101-105.

Solarek, D. 1986. Phosphorylated Starches and Miscellaneous Inorganic Esters, in O.B. Wurzburg (ed.). Modified Starches. Properties and Uses. CRC Press. Boca Raton. 97-112.

Stahl, J.A., Lobato, L. P., Bochi, V. C., Kubota, E. H., Gutkoski, L. C., Emanuelli, T. 2007. Physicochemical properties of Pinhão (Araucaria angustifolia, Bert, O. Ktze) starch phosphates. LWT - Food Science and Technology. 40: 1206-1214.

Sugih, A. K., Dewi, A., Yukano, D., Muljana, H. 2016. A Preliminary Study on the Synthesis of Phosphorylated Sweet Potato (Ipomoea batatas L.) Starch. in L. Sutiarso and H. Z. Amanah (Ed.). Recent Technology on Agricultural and Biosystem Engineering, Proceedings of the 2nd International Symposium on Agricultural and Biosystem Engineering. Departemen Teknik Pertanian, Fakultas Teknologi Pertanian Universitas Gadjah Mada. Yogyakarta. C18.1-C18.5

Sugih, A. K., Muljana, H., Surya, W., Anggraini, T.M. Synthesis and Characterisation of Phosphorylated Sago (Metroxylon sago) Starch. 2013. in Starch Update-2013, Proceedings of the 7th International Conference on Starch Technology. National Center for Genetic Engineering and Biotechnology (BIOTEC). Bangkok. 91-96.

Sugih, A. K., Nathania, I., Muljana, H. 2015. Synthesis and Characterisation of Phosphorylated Arrowroot (Maranta arundinacea L.) Starch. in Starch Update2015, Proceedings of the 8th International Conference on Starch Technology. National Center for Genetic Engineering and Biotechnology (BIOTEC). Bangkok. 65-70

Wina, E., Evans, A. J., Lowry, J. B. 1986. The Composition of Pith from the Sago Palms Metroxylon sagu and Arenga pinnata. Journal of the Science of Food and Agriculture. 37: 352-358. 